\title{
Old-New Challenges? Poverty and Menstruation: Young Girls and Women in the Mirror of Disadvantaged Situation
}

\author{
Anna Perge \\ Faculty of Health, University of Miskolc, Assistant professor \\ Andrea Rucska
}

$\mathrm{PhD}$, Faculty of Health, University of Miskolc, Associate professor

\section{Abstract}

Disadvantaged situation means not just a kind of negative social phenomenon, but its effects manifesting on the economic and social fields are also significant. Regarding its complexity, a holistic view is necessary to approach it, and explore the developed situation, define solution proposals, promote a better quality of life and finally, to monitor prevention processes and revise the proposals if necessary. In case of disadvantaged situation, the involvement of children and women requires special attention in all aspects. The Creative Region research group launched its various research in the multi-stage research of the Higher Education Institutional Excellence Program (in Hungarian: Felsőoktatási Intézményi Kiválósági Program, FIKP) started in 2018 on the University of Miskolc, in which the staff of the Faculty of Health got the opportunity to conduct the comprehensive health mapping of the rural population with the involvement of 25 settlements. Based on the results of the FIKP research, it has been supported from more approaches that disadvantaged situation and deprivation can significantly determine the health behaviour, health consciousness and future life prospects of people living there. The comprehensive research examined the characteristics of the health status of people living in disadvantaged settlements along different dimensions. Getting to know the mental health of young girls and the issue of menstruation days among both them and the adult female population were essential elements of the research. During data recording in 2018 with student girls under the age of 14, we experienced in a high number that the girls' mental well-being was not ideal, and this also manifested in mild to moderate depression at more of them. The presence of domestic violence affecting them is also not negligible in the region. Our research performed in 2019 also supports that anxiety and the feeling of shame appear strongly among young girls on menstruation days as well, and a certain level of the omission of menstruation hygienic products can also be experienced in the 
region. Data collection performed in 2020 focused on the adult female population in which we experienced the similar phenomena as in case of young girls. In connection with showing the direction of the areas to be improved and defining the promoting prevention health promotion advice, we should have had to strive for adapting to the population's demands and the professionals' flexibility which support the more favourable acceptance of the proposals. The significance of individual care, individual competence improvement and personalized counselling and help is indispensable.

Keywords: poverty, disadvantaged situation, young girls, women, menstruation

\section{Introduction}

Public awareness is still interpreting the definition of poverty from selected points of view: it is limited to the lack of infrastructural conditions, the lack of adequate quantity and quality of food, or the omission of certain tangible assets. But what could be the consequences of that if this broad definition with a comprehensive meaning ${ }^{1}$ is approached only from certain sides? All these can cause that issues on the "fringe" will be pushed to the background, and measures to eliminate poverty are often aimed to the cessation of the mentioned deficiencies. In terms of the areas mentioned less, the issues of intimate hygiene and experiencing the closely relating menstruation days are especially significant.

In Hungary, children in the period of sexual maturation are helped with information lessons to understand the process of menstruation, and the issues of personal hygiene and healthy lifestyle are emphasized in the transfer of health-related information during teaching health sciences (Ministry of Public Welfare Decree No. 26/1997. (IX. 3.) on school-health services). Besides these, the field of women's protection is also emphasized among the tasks of primary health care (Ministry of Health, Social and Family Affairs Decree No. 49/2004. (V. 21) on Regional Midwife and Health Visitor Service. In Hungary, thanks to several initiations, young girls and women living in difficult circumstances have received disposable products in the last years ${ }^{2}$, however, menstruation is still often a taboo topic. And the issues of menstruation and the existence of intimate hygiene products hardly ever come up in connection with poverty.

\footnotetext{
${ }^{1}$ Rudolf ANDORKA discusses the issues of deprivation, disadvantaged situation, highly disadvantaged situation, absolute poverty and relative poverty under the definition of poverty in his approach. 2The \#lánybólnővé (\#fromgirltowoman) program of the Hungarian Red Cross in the school year of 2019/2020 and the staff of the Faculty of Health, University of Miskolc in the frames of the FIKP project in 2020 transferred the donations collected by the \#nemluxustáska campaign (\#notluxurybag campaign) to disadvantaged settlements.
} 
The question is how poverty influences a biological process that is accompanied to a woman's life for decades from the occurrence of menarche, such as poverty as well, so these two are inseparable, and they should be treated together.

Several initiations aimed to terminate poverty and fight against inequalities can be found globally, and so in Europe (Ksh, 2020). The fight against poverty and the reduction of its consequences has special significance in Hungary. A project of the University of Miskolc has been launched in 2018 with the permission of a research ethics committee ${ }^{1}$, under the name of Higher Education Institutional Excellence Program (In Hungarian, Felsőoktatási Intézményi Kiválósági Program, hereinafter: FIKP).

\section{Literature Review}

\section{Justification of the research}

The 25 settlements involved in the FIKP program were selected from one of the most underdeveloped regions of Hungary, the region of Abaúj in Borsod-Abaúj-Zemplén County (Rucska et al., 2020a). The settlements of the region involved in the research are beneficiary from socio-economic and infrastructural aspects, and/or they are settlements where unemployment significantly exceeding the national average should be expected [Government Decree No. 105/2015. (IV. 23) ]. The staff of the Faculty of Health, University of Miskolc has set itself the goal to get know the health status of the region's population based on monitored data, and they intended to map the factors affecting it. The multi-stage research focused primarily on the children population (Rucska et al., 2020b), and then the adult population.

During the research, it has been supported from several approaches that disadvantaged situation and deprivation have negative effects on children's development (Fritz \& Perge, 2020). Children's poverty is not limited to only the financial aspect, but a much more wider interpretation is also needed to map the affected children's future life prospects and life chances (Perge et al., 2019). It is not a negligible certainty that due to poverty or financial deprivation, several factors can be observed among families raising children that significantly contribute to the negative influences on children's development (Perge, 2021). To represent the problem's complexity, the factors influencing the health of families nursed in the settlements should be approached among different dimensions, which can often occur as chance disadvantages in terms of children's development (Perge, 2019).

In social terms, it manifests in the high vulnerability rate ${ }^{2}$, which can develop due to health and/or social reasons (Perge et al., 2020a). All of these have effects on children

\footnotetext{
1 The study was approved by the Regional Research Ethics Committee (IG-102-298/2018)

2 In Hungary, there is a legally secured, organized system in the issue of children's vulnerability: we should pursue to prevent vulnerability and complications even from the prenatal period, from the registration of a pregnant woman, and to recognize them in time [Ministry of Human Capacities Decree
} 
directly. The affection of children from the aspect of vulnerability requires increased care in all cases. The help of professionals getting in connection with the family during nursing includes tasks necessary for the families' everyday life, transferring specific knowledge, and teaching necessary skills for the daily activities to contribute to the organic, mental and social development of children requiring special care, promoting their social development and guide them to a positive direction. By holistic thinking and cooperation, as a team-work, professionals can take essential steps to improve the affected people's health status and life conditions in order to reach a better quality of life (Perge, 2020).

The occurrence of the high proportion of families unable to heat their homes sufficiently should be mentioned. Inappropriate housing conditions have also emerged from the data in families expecting or parenting a child ${ }^{1}$ : such as not resolved wired drinking water or gas supply, the lack of a restroom or the high rate of non-flashing toilets. The existence of a bathroom has also showed deficiencies. Vulnerability and the number of people living in the same household occurred in inverse proportionality. On average, 6.2 persons lived in the same household in socially and medically vulnerable families, 4.6 persons in only medically vulnerable families and 6 persons lived together in only socially vulnerable families. In households where no vulnerability presented during the data recording, 4 persons lived together on average (Perge et al., 2020a). Data processed in the research have highlighted that these serious house quality problems, housing poverty affects a great part of the region.

Besides that disadvantaged situation is a socio-economic problem, it is a medical problem as well. Both quality and quantity deficiencies of nutrition could be detected in the research performed among children living in disadvantaged settlements (Sztojev-Angelov, 2020). In connection with oral screening in the study of Faragó et al. (2020), in which 128 students were involved, the lack of permanent teeth, children's low or completely missing motivation, and, additionally, the parents' socioeconomic situation and their inadequate example setting also mean a great problem besides the infrastructural and dental care deficiencies (total absence of the number of filled teeth). Based on the data of the FIKP research (Perge et al., 2020b), the

No. 26/2014. (IV. 8) on Pregnant Care]. Besides these, enhanced monitoring and help, the increased care itself is ensured in case of vulnerability from new-born age to the time when starting student status, during children's care [Ministry of Health, Social and Family Affairs Decree No. 49/2004. (V. 21) on the Regional Midwife and Health Visitor Service]. The professional(s) getting in connection with affected families in a nursing-educational institution are the members of a signing system [Ministry of Public Welfare Decree No. 26/1997. (IX. 3) on school-health services]. Disadvantaged and highly disadvantaged children and students require special attention [Act CXC of 2011 on National Public Education].

1Pregnant women, families parenting a child/children aged 0-6 and children aged 7-18 and not visiting any educational institutions were listed here. 
parents' financial situation is also likely to contribute to that children with visual problems do not have glasses and they do not visit ophthalmic care regularly.

In 2018, Rucska et al. (2020c) mapped the mental health of girls under the age of 14, what was also extended to the diagnostic condition assessment and the effects of the protecting factors. The values of the development of anxiety increase by the progression of age ( $p=0.012)$, and significant difference could be experienced in case of genders ( $p=0.00012)$; girls are more anxious than boys. A medium strength correlation could be detected between depression and anxiety $(\mathrm{r}=, 47)$. Children involved in the research, based on their own confessions: 5.5\% of them are victims of domestic violence, and several of them are afraid of a person who could hurt them physically. These persons live mostly in the children's environment, and this type of violence affects young girls more often. School violence also occurs among the answers, and its victims are mostly boys. The lack of social relationships could also be observed in more children, they do not share their feelings with anybody. More than $50 \%$ of the youngsters tell their problems to friends, $27.5 \%$ discuss their problems with their parents (Rucska et al., 2020c).

In case of disadvantaged situation, the involvement of children and women requires special attention in all aspects. Children need special attention, since the effects of disadvantaged situation occur in numerous fields in their case, in terms of heath culture and health behaviour among others. Children growing up in poverty live among us, so do girls live in menstrual poverty. This social, economic and medical problem requires studies that are aimed to the affected children population and the menstruation issues affecting them.

\section{Methodology}

\subsection{Research goal}

The comprehensive research focused on young girls and women living in disadvantaged settlements. Its goal was the mapping of girls' mental state linked to menstruation in the period of menarche, and the examination of certain intimate hygiene habits on these days among them. In case of the adult female population, we intended to examine their mental condition and their menstruation-related habits already existing. Additionally, the aim of the research was providing a kind of guideline for professionals to define prevention activities in the area in the mirror of the results, by highlighting the possible points of intervention.

\subsection{Materials and Methods}

The examination was preceded by wide literature review, the results of the FIKP research started in 2018 on the University of Miskolc created the baseline of the study, and the issue of menstruation of adolescent girls living in disadvantaged settlements came to the foreground as the next step of the multi-stage empirical research. The program called \#lánybólnővé organized by the Hungarian Red Cross 
happened at the time of the research, during which student girls in class seven of the primary schools of 13 disadvantaged settlements connected to the program ${ }^{1}$, and the campaign called \#nemluxustáska was also organized in January 2020 by the Hungarian Maltese Charity Service ${ }^{2}$. The research was conducted by connecting the experiences gained on these different fields, by focusing on the certain social and also medical problem. Disadvantaged situation was the main direction of the quantitative empirical survey, and within this, menstruation and mental status topics were examined (including but not limited to). Priorly, based on the feedback of the school directors and professionals taking part in the nursing-parenting processes, none of the girls showed signs for that taking the questionnaire would not present real results because of any excluding causes.

We received the examination data by taking a questionnaire. Data recording of the questionnaire happened by the help of measuring commissioners both among young girls and adult women. In case of the young girls, we used a questionnaire by which children could characterize themselves (Perczel-Forintos, 2018): the children's version of the Spielberger's adult State-Trait Anxiety Inventory developed in 19733 that is suitable for measuring the anxiety level of schoolchildren. By filling the validated questionnaire, the achieved score could be minimum 20 and maximum 60 . Counting the total score, the values above 38 show high anxiety level in case of state anxiety. Adapting the questionnaire by the help of the 20 items of the State Anxiety Inventory during the research, besides mapping the mental status related to menstruation, it had been complemented by questions on certain hygienic habits. Some of the items were analysed separately, because regarding the situation, they are able to provide a guideline for professionals independently in the field of preventive interventions as well. The research strived to get answers for $100 \%$ of the statements. In the end of the questionnaire, the respondent girls had the opportunity to write down their questions (in a lot of cases, they did not want to ask in front of their mates), which were answered after the collection of the questionnaires, ensuring anonymity.

The children's parents/guardians had priorly received written information about the program ${ }^{4}$, and then, based on the information included in the leaflet, they filled a written declaration of consent. The research was performed in a 3-month period from October 2019 to December 2019. During this period, 185 student girls in class seven of the primary schools filled in the questionnaire, and 140 questionnaires were assessable after clearing data. Since we strived for providing calm and safety

\footnotetext{
${ }^{1}$ I joined to the program as a volunteer, I made information discussions in the schools as the teacher of the Faculty of Health, University of Miskolc and also as a health visitor.

2The University of Miskolc provided several sites for the campaign.

${ }^{3}$ State-Trait Anxiety Inventory for Children, STAI-C, Spielberger, C. D. 1973, translated by.: K. SIPOS

The leaflet detailed the followings: permission of the program, goals of the program, requests for parents/guardians, the content of the questionnaire, a short information presentation for children, the voluntary and free availability of the program, information for confidentiality.
} 
atmosphere and excluding disturbing external effects during data recording (we did not look into the answers during answering), more girls could not give scorable answers.

The designation of disadvantaged situation did not apply to persons, we took it into account at choosing settlements and schools. The mean age of the sample was 12.96, the youngest respondent was 12 years old, the oldest was 15, its median was 13.23 student girls marked the "not menstruating yet" answer. At the time of data recording, $27.89 \%$ of the respondents marked that they were menstruating on that day, so we are talking about a retrospective trial in case of $72.11 \%$ of the respondents. According to the best of our currently knowledge and possibilities, we are unable to ensure that all the girls fill in the questionnaire at the time of their menstruation: human resources are not available for this, and we have to count with the infrastructural deficiencies as well (not everyone has a smart phone via which she could reach the questionnaire), and anonymity would also not be ensured in all the cases.

Data collection among adult women was performed in 25 disadvantaged settlements, during which we used the Spielberger State-Trait Anxiety Questionnaire and Beck's Depression Questionnaire over the items focusing on demographic background information and menstruation. The Spielberger state anxiety or momentary anxiety self-filled questionnaire consists of 20 items (Perczel-Forintos, 2018). The scale is suitable to assess anxiety as a personality trait, to measure interim anxious conditions characterized by the feeling of fear experienced subjectively, anxious waiting and the feeling of conscious tension, and resulting in the increased excitement of the operation of the vegetative nervous system. The experience changes for the effect of environmental changes. The questionnaire shows the value of the strength of the tendency to anxiety. The applied questionnaire contained 20 items; the respondent could give points from 1 to 4 according to how much the statement was typical for her. The level of anxiety is assessed based on the total score and compared to a standard value (Rucska et al., 2020c). The value of the scale is minimum 20, maximum 80 points. The questionnaire was filled by 203 women between the age of 18 and 83 , and their mean age was $39.4 \pm 15.4$ years. Women involved in the examination live in highly disadvantaged settlements of Abaúj region. Most of the participants have low educational level $(8.4 \%$ is under the basic qualification, $31.8 \%$ has basic qualification). $66 \%$ of the respondents have a job. Most of the non-working respondents raise children (30\%), live from temporary jobs $(21.3 \%)$, are searching for a job or retired (18.8\%), and some of them are students (7.5\%). Most of them are married $(43.1 \%)$ or live in a cohabiting or partner-like relationship (11.1\%). 11.1\% of the examined women are single, $3.2 \%$ is divorced and $7.5 \%$ is widow. $13.3 \%$ of the women are currently pregnant. 


\section{Results}

\subsection{The occurrence of anxiety among children on the menstruation days}

The first part of data recording focused on mapping the mental state during the days of menstruation. By the state anxiety questionnaire, the lowest point is 23 and the highest is 54 that shows a very high anxiety level, and it could be detected at only 2 persons in the sample. A great part of the student girls giving valuable answers $(58.57 \%)$ got 38 or a score above it which was considered as quite strong anxiety. The anxiety level during menstruation was lower at $5.71 \%$ of the respondents, it was under 30 points (Figure 1). One of the girls showing the highest anxiety level menstruated on the examination day.

Figure 1: State anxiety level during menstruation

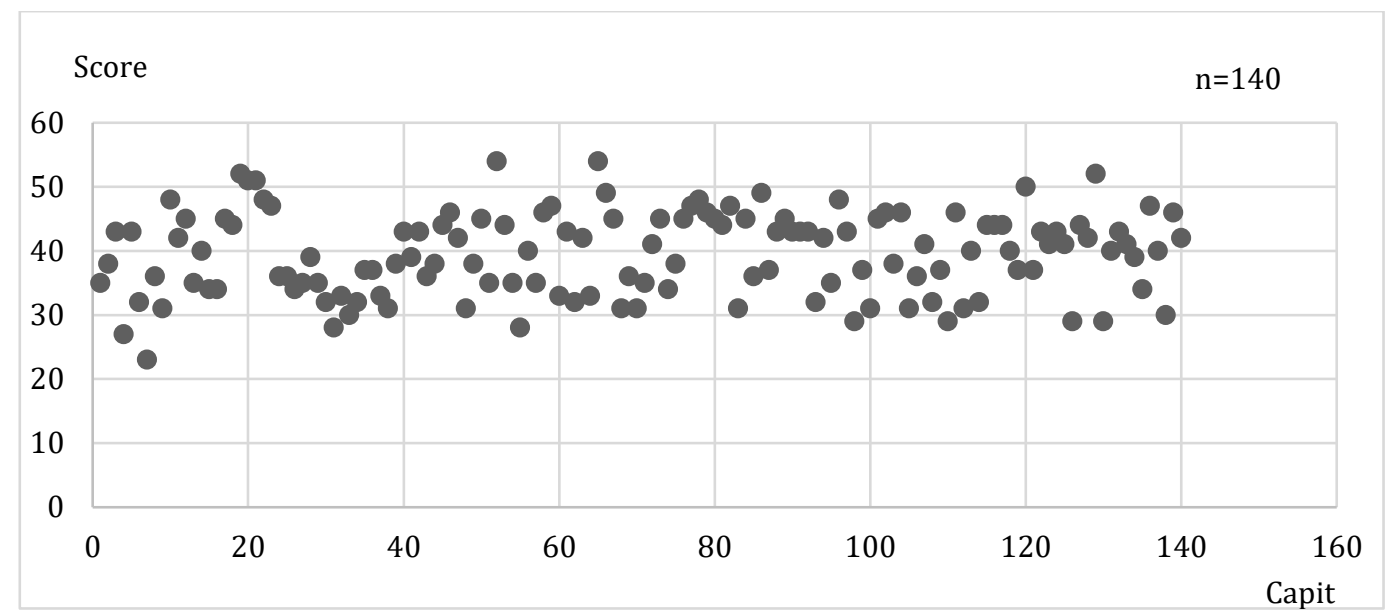

Source: edited by the author

The research also dealt with the issue of shame. $80.92 \%$ of the student girls marked that feeling ashamed happens with them during menstruation. $78.29 \%$ of the respondents also marked its frequency. Always, often and sometimes were marked in closely the same rate. According to the answers, 29.41\% always feels shame during her menstruation period, $31.1 \%$ feels it often and $30.25 \%$ marked sometimes. Among those who marked the frequency of feeling shame, 9.24\% feels it rarely during her menstruation (Figure 2). 
Figure 2: Frequency of shame during menstruation

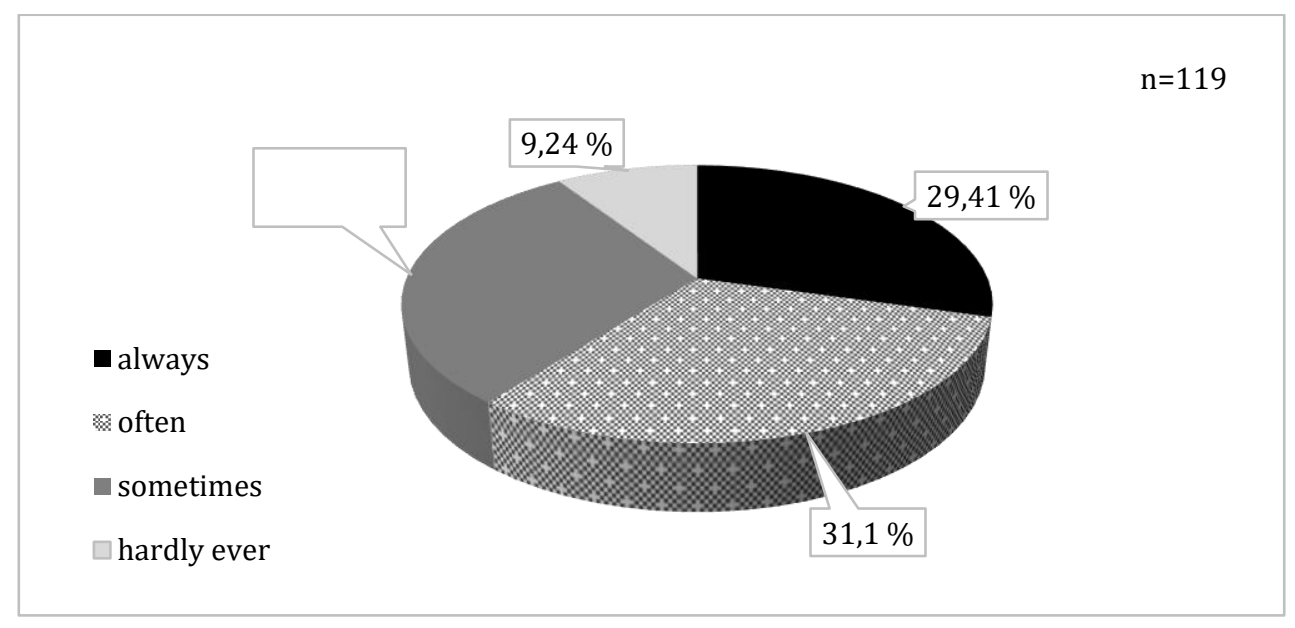

Source: edited by the author

\subsection{Intimate hygiene habits among young girls}

The research focused on the category of used products; quality issues were not examined. Most women of the sample marked the use of sanitary pads, often combined with pantyliners. The respondents marked the use of pantyliners in more cases, and it is essential to mention here that products on the Hungarian market contain more pieces than in case of sanitary pads. One respondent marked the use of tampon besides sanitary pad.

A 13-year-old girl, who had her first menstruation at the age of 12, uses pantyliners and old clothes and textiles to catch menstruation blood, which are changed in almost every hour at home and in almost every break in the school. In her case, the anxiety level was experienced to be high with 46 points, and according to her answers, she often feels shame during her menstruation.

3 girls from the sample answered that they use handkerchiefs besides pad(s). Two of them showed high anxiety level on the state anxiety scale, although, all the three of them feel some shame on the menstruation days.

Habits were examined from another perspective as well: according to the using interval of the products. Regarding the frequency of changing these products during menstruation, one girl marked that she changed pads maximum twice at home and once in the morning at school. Regarding her anxiety level (41 points), she received a high score, and based on her answers, she often feels shame in these periods. Two girls answered that they change pad once a day at home, one of them twice a day at school. In their cases, one girl's anxiety level was 44 points, the other menstruated on 
the day of answering, and according to her answers, she always feels shame during her menstruation.

In connection with habits on school days, we experienced that 13 persons do a change once during staying at school in the morning, 22 persons do this maximum twice and 4 persons do not change any products at school. Among girls staying until the end of the afternoon lessons, 2 persons change maximum twice, 1 does not change, 1 does not change or maximum once in the afternoon and 1 person changes once in the morning.

\subsection{Hidden "messages"}

The respondents had the opportunity to ask questions both orally and written, from what we could get an image about the issues concerning the girls mostly in connection with menstruation. They were also interested in other areas, such as sexuality and certain gynaecological issues that often occur as taboo topics among them. Extremes can be felt very strongly in connection with the topic, questions related to the reception of menstruation occurred in one class, but others in the same group were interested in the topic of pregnancy and sexuality.

The age when menstruation had occurred among the girls was recorded in the research. The earliest menarche in the sample was at the age of 9 , the latest was at the age of 14, its median was 11 . The difference between the menarche data and the mean age of the sample (12.96 years) was almost 2 years. In this approach, the demand for presentations for information lessons and creating efficient habits occurs in the lower classes of the primary school.

\subsection{The issue of adult women's menstruation}

In case of the adult women, we asked them about what they used for catching menstruation blood (Table1). The respondents could mark more products as well.

Table 1: Devices used for catching menstrual discharge

\begin{tabular}{|l|l|}
\hline 1. sanitary pad & $58.8 \%$ \\
\hline 2. tampon & $39.4 \%$ \\
\hline 3. pantyliner & $20.4 \%$ \\
\hline 4. cotton & $2.3 \%$ \\
\hline 5. paper handkerchief & $2.3 \%$ \\
\hline 6. clothes, textile & $0.9 \%$ \\
\hline
\end{tabular}

Source: edited by the author

It can be observed that sanitary pads are the most used tools. Women using sanitary pads mostly use pantyliners as well $(\mathrm{r}=0.328)$, as tampon usage is also accompanied by pantyliners $(\mathrm{r}=0.524)$. Other textiles, cotton and paper handkerchiefs are used by 
women with lower education level, while more qualified women prefer sanitary pads and tampon.

$6 \%$ of the respondents answered that it had happened that she had not had anything to use during menstruation. Its frequency was quite variable (Table 2).

Table 2: Frequency of the lack of tools

\begin{tabular}{|l|l|}
\hline Frequency & Percentage \\
\hline monthly & 46.2 \\
\hline More times every six month & 15.4 \\
\hline Every six month & 3.8 \\
\hline A few times a year & 11.5 \\
\hline Maximum once a year & 19.2 \\
\hline
\end{tabular}

Source: edited by the author

It can be observed from the answers that it happens with $46.2 \%$ of the affected women monthly that they do not have anything for catching menstruation discharge. This tool deficiency happens with women who marked tampon $(\mathrm{r}=0.254 ; \mathrm{p}<0.005)$, cotton $(\mathrm{r}=348 ; \mathrm{p}<0.005)$, paper handkerchief $(\mathrm{r}=0.4 ; \mathrm{p}<0.001)$ and textile $(\mathrm{r}=0.269 ; \mathrm{p}<0.034)$ as a catching tool.

In terms of anxiety, the mean value of the asked women is $43.5 \pm 7.5$ which corresponds with an average anxiety level, but $10 \%$ of the respondents fall into the critical range ${ }^{1}$. Women using tampon $(\mathrm{r}=0.216 ; \mathrm{p}<0.017)$ and paper handkerchief $(\mathrm{r}=0.344 ; \mathrm{p}<0.005)$ during menstruation for catching blood are the most anxious.

\section{Discussion}

Regarding the answers of girls living in disadvantaged settlements examined in the occurrence period of menarche, most of them show strong anxiety level during menstruation (58.57\%) based on their subjective judge. We are talking about a retrospective trial in most cases, but it can be observed as a tendency that shame also strongly occurs (80.92\%) besides the high anxiety level among young girls during the days of menstruation, which happens mainly always, often and sometimes. Similarly to the examination of Rucska et al. (2021c), the method applied in our research has been proved to be effective among both young girls and women living in disadvantaged settlements. During the earlier examination, a significant difference could be detected in case of genders: student girls under the age of 14 were more anxious than boys (Rucska et al., 2021c); in this current research, the analyses of the

1Values above 53 points mean serious anxiety. 
mental state of seventh grade girls on menstruation days also show the powerful occurrence of anxiety among them. In connection with the intimate hygiene products, deviation can be detected in both of the used products and the frequency of their changes. Different interests may be given by the problems of the age. The different ages and biological particularities could result in that further questions emerged over menstruation in terms of sexual behaviour and gynaecological problems.

In those women who often suffer from the lack of tools during menstruation, a high percentage of them misses these tools monthly. Higher anxiety level is typical for those in their case, who use tampon and paper handkerchief on the days of menstruation.

\section{Conclusion}

We have to strive for reducing the negative effects of disadvantaged situation on children as early as possible. A holistic point of view is necessary to approach and explore the problem, and to provide proposals for the solution.

During our efforts for changes, flexibility and the adaptation of the population's demands is indispensable from the health and educational professionals. Promoting the health-conscious lifestyle of the growing generation is a complex exercise. Besides the presence of professionals, it requires the receptive behaviour of children and their educators, parents.

Regarding that the relationship between menstruation and poverty is a less researched field, the national and international literature difficult to be found justifies further research. A comprehensive research approaching from different dimensions would be necessary on the field, which would examine the differences between generations, and analyse how much disadvantage situation affects the experience of menstruation days. Besides this, in future studies, drawing further evidentiary conclusions would be necessary by the increase of the element number and the conduction of in-depth interviews.

\section{References}

[1] Ministry of Public Welfare Decree No. 26/1997. (IX. 3) on school-health services

[2] Hungarian Regulation of pregnancy care approved by Ministry of Human Capacities: 26/2014. (IV. 08.)

[3] Ministry of Health, Social and Family Affairs Decree No. 49/2004. (V. 21.) on Regional Midwife and Health Visitor Service

[4] Government Decree No. 105/2015. (IV. 23.) on the classification of the beneficiary settlements and the condition system of the classification.

[5] Act CXC of 2011 on national public education. 
[6] Andorka R. (2006): Bevezetés a szociológiába. Osiris Kiadó

[7] Faragó I., Sztojev- Angelov I., Perge A., Rucska A. (2020): Szájüregi szűrés. In: Kiss-Tóth, Emőke (editor) Abaúj térség 14 év alatti gyermeklakosságának egészségmagatartása és fejlesztési lehetősége. Miskolc-Egyetemváros, Magyarország : Miskolci Egyetemi Kiadó

[8] Fritz P., Perge A. (2020): Egészségfejlesztő életmódprogram lehetséges elemei - intervenciós terv. In: Kiss-Tóth, Emőke (editor) Abaúj térség 14 év alatti gyermeklakosságának egészségmagatartása és fejlesztési lehetősége. Miskolc-Egyetemváros, Magyarország: Miskolci Egyetemi Kiadó, pp. 99-101.

[9] Ksh (2020): Fenntartható fejlődési célok. Online available: Fenntartható fejlődési célok (ksh.hu)

[10] Perczel-Forintos, D. Ajtay, Gy. Kiss Zs. (editor) (2018): Kérdőívek, becslőskálák a klinikai pszichológiában. Semmelweis Kiadó, Budapest

[11] Perge A. (2019): Hátrányos helyzetű településeken gondozottak az egészségmagatartás tükrében, avagy az egészségnevelés lehetőségei hátrányos helyzetű településeken gondozottak körében. In: Karlovitz, János Tibor; Torgyik, Judit (editors) Szakmódszertani és más emberközpontú tanulmányok. Komárno, Szlovákia: International Research Institute, pp. 343-348.

[12] Perge A. (2020): A veszélyeztetettség ismeretének jelentősége: A speciális ellátás és gondozás témakör a szakmai tanárképzésben. In: Torgyik, Judit (editor) Társadalmi felelősség és szociális gondolkodás. Grosspetersdorf, Ausztria: Sozial und Wirtschafts Forschungsgruppe, pp. 88-94.

[13] Perge A. (2021): Kompetenciák súlya a hátrányos helyzetű településeken élők egészségmutatóinak javítására történő törekvésekben. Multidiszciplináris Tudományok: a Miskolci Egyetem közleménye 11:2 pp. 334-340.

[14] Perge A., Rucska A., Kiss-Tóth E. (2019): Health education as a possible intervention in the child population living in disadvantaged settlements. In: Karlovitz, Tibor János (editor) Theory and Practice: Lifelong Experiences, Grosspetersdorf, Ausztria: Sozial und Wirtschafts Forschungsgruppe, pp. 6570.

[15] Perge A., Rucska A., Kiss-Tóth E. (2020a): A védőnői ellátottság jellemzői és az arra hatást gyakorló tényezők a vizsgált települések vonatkozásában. In: Kiss-Tóth, Emőke (editor) Abaúj térség 14 év alatti gyermeklakosságának egészségmagatartása és fejlesztési lehetősége. Miskolc-Egyetemváros, Magyarország: Miskolci Egyetemi Kiadó, pp. 19-34. 
[16] Perge A., Sztojev-Angelov I., Rucska A. (2020b): Érzékszervi vizsgálatok a 4., 6. és 8. osztályos tanulók körében. In: Kiss-Tóth, Emőke (editor) Abaúj térség 14 év alatti gyermeklakosságának egészségmagatartása és fejlesztési lehetősége. Miskolc-Egyetemváros, Magyarország: Miskolci Egyetemi Kiadó

[17] Rucska A., Faragó I., Semanova Cs., Perge A., Sztojev-Angelov I., Kiss-Tóth E. (2020a): Anyag és módszer. In: Kiss-Tóth, Emőke (editor) Abaúj térség 14 év alatti gyermeklakosságának egészségmagatartása és fejlesztési lehetősége. Miskolc-Egyetemváros, Magyarország: Miskolci Egyetemi Kiadó, pp. 15-18.

[18] Rucska A., Felszeghi S., Perge A., Sztojev-Angelov I., Kopkáné Plachy J., KissTóth E. (2020b): Kutatási cél. In: Kiss-Tóth, Emőke (editor) Abaúj térség 14 év alatti gyermeklakosságának egészségmagatartása és fejlesztési lehetősége. Miskolc-Egyetemváros, Magyarország: Miskolci Egyetemi Kiadó, p 14.

[19] Rucska A., Kopkáné P. J., Valikovics A. (2020c): Mentális egészség. In: KissTóth, Emőke (editor.) Abaúj térség 14 év alatti gyermeklakosságának egészségmagatartása és fejlesztési lehetősége. Miskolc-Egyetemváros, Magyarország: Miskolci Egyetemi Kiadó

[20] Sztojev-Angelov I. (2020): Táplálkozási szokások vizsgálata halmozottan hátrányos helyzetű gyermekeknél. In: Kiss-Tóth, Emőke (editor) Abaúj térség 14 év alatti gyermeklakosságának egészségmagatartása és fejlesztési lehetősége. Miskolc-Egyetemváros, Magyarország : Miskolci Egyetemi Kiadó 